\title{
Empowering wageseekers? The computerisation of India's NREGA in Andhra Pradesh
}

[SF blogs.Ise.ac.uk/southasia/2016/07/25/empowering-wageseekers-the-computerisation-of-indias-nrega-inandhra-pradesh/

Silvia Masiero and Diego Maiorano recently visited Andhra Pradesh to study the computerisation of NREGA, India's largest workfare scheme. They argue that the provision of open data through a dedicated information system increases transparency, but does not automatically result in wageseekers' empowerment.

India's National Rural Employment Guarantee Act (NREGA) is the country's largest workfare scheme. Started in 2006, it provides a legal guarantee of 100 days of employment in public works per year to members of rural households who demand it. Based on the principle on non-excludability of the right to work, NREGA has yielded positive effects on income generation for below-poverty-line households, whose members are guaranteed minimumwage work towards improvement of local infrastructure. The programme has also had significant effects on labour markets, through wage increases and reduction of distress migration to urban areas.

But the system is affected by a range of issues at the national and sub-national level. One problem is related to the discretionary basis of allocation of NREGA work: though the programme should function as a post-clientelistic policy, shrinking budgetary allocations by the central government make it challenging to assign work to anyone who demands it. Another issue relates to wage payments, whose incomplete and delayed delivery affects a rising proportion of workers: implementing agencies are separated from disbursement bodies, which makes it difficult to assign responsibilities when payments are missing or late. This is particularly problematic for NREGA's functioning, since wage payments constitute the core entitlement for which the programme has been designed.

Over the last few years, several state governments have engaged in digitisation as a means to tackle existing issues with NREGA. End-to-end computerisation is increasingly utilised to streamline the functioning of social safety nets, and to maximise accountability of government providers for the services to which citizens are entitled. Frontend computerisation - largely enabled by biometric devices - was restrained until very recently, by the Supreme Court of India order (September 2013) forbidding to make access to anti-poverty programmes conditional to Aadhaar registration. But with the Aadhaar (Targeted Delivery of Financial and other Subsidies, Benefits and Services) bill, passed as money bill in March 2016, Aadhaar can now be inscribed in anti-poverty programmes, which influences the requirements for access to the nation's social safety infrastructure.

Computerisation affects the politics of anti-poverty programmes in diverse ways, regulating access and translating ideas of development policy into practice. Designed to streamline the functioning of India' anti-poverty system, digitisation can have transformative effects on NREGA, directly affecting the entitlements of beneficiaries and their access to the workfare scheme. Given the rapid uptake of e-governance across the nation, it is therefore important to study how technology influences the programme, and investigate how these mechanisms work in practice for NREGA. 


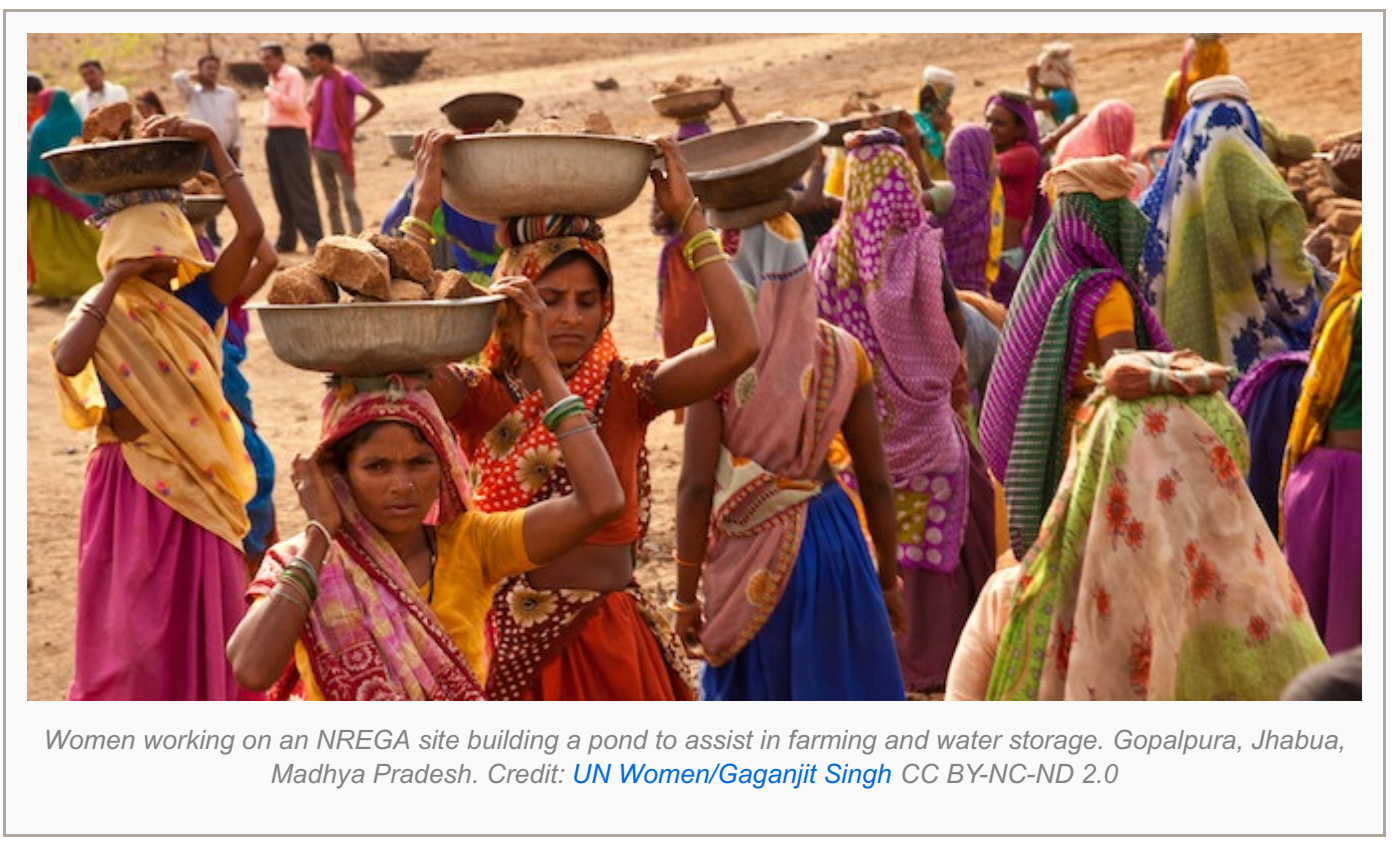

We have done so through a study of the information system for NREGA in Andhra Pradesh (AP), one of the national top spenders and performers on the programme. Since 2006, AP NREGA works through a management information system which translates all programme's transactions into open data, making them universally accessible online. Information pertains to all phases of the programme, including generation of works, procurement, allocations and payments, in order to combat leakage through systemic monitoring of fund flows. Transaction information is found on the government website, enacting the principle of transparency for greater accountability of the scheme.

As the system is further developed, the payment infrastructure is being integrated with biometric recognition of users by disbursement agencies, a step now legally enabled by the recent Aadhaar bill. In the system as it is designed, transparency is meant to combat the illicit capture of funds, to ensure that transactions unfold correctly and are constantly monitored from the public. This should help ensuring that wageseekers are paid the right amount for each batch of work, and that payments are received in a timely manner for each allocation. Transparency also contributes to the state government's image, which demonstrates its dedication to NREGA through the construction of a dedicated information system.

At the same time, workers' narratives collected on the field problematise the extent to which the system makes the programme more accountable. Payments' processes, computerised only until funds reach the disbursement agencies, are then left in the discretion of banks and post offices: this makes it difficult to trace the most crucial stage of the process, the one in which payments are actually disbursed. When biometric recognition is enabled it will prevent the inclusion of non-entitled workers, but does not solve the exclusion error that leaves legitimately entitled wageseekers with incomplete or missing wages. The logic underlying biometric recognition - while making the wageseeker accountable to the provider - does not work for downward accountability, as it does not per se guarantee provision of the right entitlements.

This is to be read in conjunction with the structure of Shrama Shakti Sanghas (SSS) groups, through which NREGA work is organised in AP. The hierarchical organisation of groups, led by a mate who exerts discretion on all works' phases, leaves limited voice to workers on internal organisation, while the task of uploading muster roll information (on which payments are based) is managed by government-appointed Field Assistants. This makes it hard for workers to check that their wages are provided correctly, as no formal mechanisms are in place to make Field Assistants accountable for muster roll administration. As a result, public information is not yet translated into a supportive infrastructure for wageseekers, to exert their rights to claim entitlements when payments are missing or lower than expected.

The Aadhaar bill 2016 lays the legal foundations for a new phase in the history of India's anti-poverty agenda, in 
which the Aadhaar-enabled recognition of users can be formally inscribed in social safety nets. This increases the importance of producing socially embedded understandings of IT systems, as they formally enter the nation's social policy. Our study of AP NREGA aims to shed some light on the politics of computerisation, and on their effects on the entitlements on which India's poor depend for their livelihoods.

Note: Full working paper available here. This article gives the views of the author, and not the position of the South Asia @ LSE blog, nor of the London School of Economics. Please read ourcomments policy before posting.

\section{About the Authors}

Silvia Masiero is a Research Officer in LSE's Department of Management and a Teaching Fellow in LSE's Department of International Development. She tweets @SilviaHedley.

Diego Maiorano is a Leverhulme Early Career Fellow at the Faculty of Social Sciences, University of Nottingham. He tweets@diegoemme.

- Copyright (C) 2016 London School of Economics 